Images in...

\title{
Hormonal effect on gingiva: pubertal gingivitis
}

\author{
Telgi R Chaitra, ${ }^{1}$ Naveen Manuja, ${ }^{1}$ Ashish Amit Sinha, ${ }^{1}$ Adwait Uday Kulkarni² \\ 1Pedodontics Department, Kothiwal Dental College and Research Centre, Moradabad, Uttar Pradesh, India; \\ ${ }^{2}$ Oral and Maxillofacial Surgery Department, Sinhgad Dental College and Hospital, Pune, Maharashtra, India
}

Correspondence to Dr Adwait Uday Kulkarni, dradwaitkulkarni@gmail.com

\section{DESCRIPTION}

A 13-year-old female patient reported to the department with pain in the gums and bleeding from the gums during brushing. On examination, there was a solitary firm gingival enlargement between 11 and 12. Marginal gingiva of lower anterior teeth was severely inflamed and bleeding on probing was present (figure 1). Generalised gingivitis was present (figure 2). History was insignificant. No other systemic findings were significant. Age of the patient and insignificant systemic findings led to the diagnosis of pubertal gingivitis. Thorough oral prophylaxis was done. Periodic recall was done for oral hygiene reinforcement. Puberty occurs between the ages of 11 to 14 in most women. The production of sex hormones (oestrogen and progesterone) increases, then remains relatively constant during the remainder of the reproductive phase. ${ }^{1}$ Kronman and Loesch ${ }^{2}$ postulated that anaerobic organisms may use ovarian hormone as a substitute for vitamin K growth factor. During puberty, periodontal tissues may have an exaggerated response to local factors. A hyperplastic reaction of the gingiva may occur in areas where food debris, material alba, plaque and calculus are deposited. The inflamed

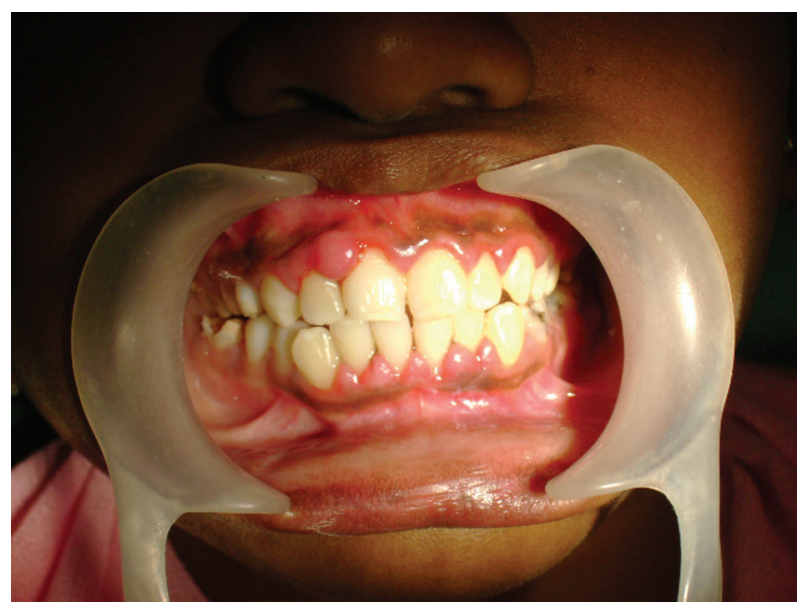

Figure 1 Gingival enlargement between 11 and 12. tissues becomes erythematous, lobulated and retractable. ${ }^{1}$ During puberty, education of the parent or care giver is a part of successful periodontal therapy. Preventive care, including a vigorous program of oral hygiene, is also vital. Milder gingivitis cases respond well to scaling and root planning, with frequent oral hygiene reinforcement. Severe cases of gingivitis may require microbial culturing, antimicrobial mouthwashes and local site delivery or antibiotic therapy. Periodontal maintenance appointments may need to be more frequent when periodontal instability is noted. ${ }^{3}$

Competing interests None.

Patient consent Obtained.

\section{REFERENCES}

1. Takei N, Carranza K. Periodontal therapy in the female patient. In: Clinical Periodontology. Tenth Edition. Netherlands: Elsevier 2007:636-37.

2. Kronman K, Loseche JF. Direct interaction of estradiol and progesterone with Bacteriodes melaninogenicus. J Dent Res 1979:58A;10.

3. American Dental Association Health Foundation Research Institute, Department Of Toxicology. Antibiotic Interference with oral contraceptives. J Am Dent Assoc 1991;122:79.

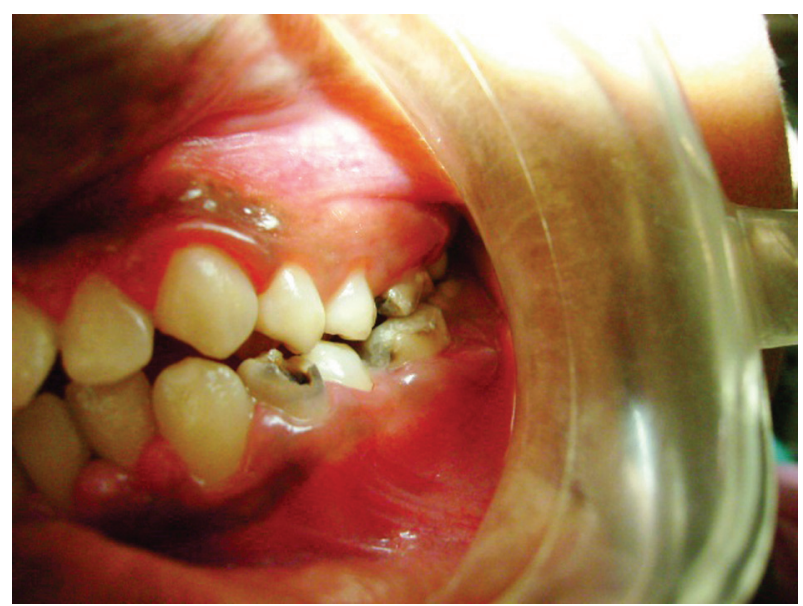

Figure 2 Generalised gingivitis. 


\section{BMJ Case Reports}

This pdf has been created automatically from the final edited text and images.

Copyright 2012 BMJ Publishing Group. All rights reserved. For permission to reuse any of this content visit http://group.bmj.com/group/rights-licensing/permissions.

BMJ Case Report Fellows may re-use this article for personal use and teaching without any further permission.

Please cite this article as follows (you will need to access the article online to obtain the date of publication).

Chaitra TR, Manuja N, Sinha AA, Kulkarni AU. Hormonal effect on gingiva: pubertal gingivitis. BMJ Case Reports 2012;10.1136/bcr.2012.006193, Published XXX

Become a Fellow of BMJ Case Reports today and you can:

- Submit as many cases as you like

- Enjoy fast sympathetic peer review and rapid publication of accepted articles

- Access all the published articles

- Re-use any of the published material for personal use and teaching without further permission

For information on Institutional Fellowships contact consortiasales@bmjgroup.com

Visit casereports.bmj.com for more articles like this and to become a Fellow

Keep up to date with all published cases by signing up for an alert (all we need is your email address) http://casereports.bmj.com/cgi/alerts/etoc 